\title{
IMPELLER RADIAL VELOCITY AND AIR FLOW RATE INFLUENCE ON COPPER ROUGHER FLOTATION RECOVERY
}

\author{
Bartosz BAZAN ${ }^{1}$, Aleksandra POTULSKA-BAZAN ${ }^{1}$, Kajetan WITECKI ${ }^{2}$ \\ ${ }^{1}$ KGHM Robinson Mine, Ruth, NV, USA \\ ${ }^{2}$ KGHM Cuprum Ltd Research\&Development Center, Wrocław, Poland
}

\begin{abstract}
A rougher flotation study has been done to analyze the effects of copper feed mineralogy, air flow rate and impeller radial velocity on metallurgical performance. During the performance testing the trials were exposed to metallurgical examining and computerised mineral analysis to establish a size-by-size mineralogy. The mineralogical and metallurgical information was compared to the material balance for rougher flotation results. These samples showed that copper recovery optimization should focus on the losses of liberated $\mathrm{Cu}$-minerals and how they are associated with fine particles.

The result of variable impeller radial velocity for each flotation cell cascade on metallurgical performance has been explored on a known-sized and an unknown-sized base, to gauge the input from the fine particles. An industrial application is discussed in this paper, and it validates that divergence of the impeller radial velocity and air flow has positive influence on the recovery.
\end{abstract}

Keywords: flotation, copper ores, liberation

\section{INTRODUCTION}

The ore-treatment process of Polish copper-ores is difficult since lithology changes and minerals size varies and both parameters cause high energy consumption. As a result of this, finding new solutions in technology of

\footnotetext{
${ }^{1}$ Corresponding author: KGHM Robinson Mine, 4232 West White Pine County Rd. 44 Ruth, NV 89319 USA, e-mail: bartosz.bazan2@kghm.com
} 
concentration, is a key element to increase the $\mathrm{Cu}$ concentrate grinding and flotation system productivity [9].

There are two aspects which need to be considered when describing the efficiency of the $\mathrm{Cu}$ concentrate production: the required $\mathrm{Cu}$ content in the final concentrate and the maximum achievable concentration. $\mathrm{Cu}$ recovery which can be described by the concentration of copper in the final tailings should be as low as possible. The availability to achieve the required ratio of $\mathrm{Cu}$ concentration between concentrate and tailings mainly depends on the liberation of $\mathrm{Cu}$ minerals. The liberation process of $\mathrm{Cu}$ minerals is carried out during grinding operations, and this is more difficult with finer ore mineralization. During the grinding processes, as a major operation of cooper minerals, the liberation of some amounts of fine and ultra-fine liberated particles occurs. Floatability of such particles is worse than the rest of partially liberated $\mathrm{Cu}$ mineral grains that are feed dedicated into the flotation operation. It is really hard to prevent the comminution circuits from generating liberated fine and ultra-fine particles in an effective way [13].

Generally, in the literature only two methods of flotation concerning fine particles have been proposed. The first solution promotes a point of view that the flotation of fine particles should be combined with the flotation of coarse particles until the moment when fine particles are taken to the froth product with coarse. The second one supports the flotation of fine particles by separating the flotation stages depending on the feed size of various particles [13]. Some reasons for the worse floatability of Polish copper ores have been investigated; finding that the necessary measures were presented in papers [2], but the conducted analysis has not been given unequivocal answers. As a result of this, increasing the concentration of fine particles needs to be recognized as one of the major challenges for Polish copper concentrators [7,11].

Based on existing industrial data it can be stated that fine particle recovery during the flotation process is related to two factors: high turbulence (achieved by energy input) and a low concentration of solids [3,6,12]. As a consequence of this, the data can be associated to flotation rates, collision frequencies and the turbulent dissipation to viscosity ratio $[5,6,10,14]$. The available market technologies connected with automated mineral analysis offer major advantages in the understanding of mineralogical characteristics of the plant and in this way provide the opportunity to investigate the influence of, for instance the impeller radial velocity and air flow on metallurgical performance of the flotation process $[8,10]$. For the purpose of this study, two sampling campaigns have been done, each of them focused on the different process parameters. Subsequent tests were designed in a way to enable collection partially the same and hence reach out comparable results. The main objective of the second sampling campaign was to collect as much data as possible to gain more information about the industrial process and 
investigate the influence of such parameters as impeller radial velocity and air flow in a wider range.

\section{CHARACTERISTICS OF POLISH COPPER ORES}

KGHM copper ore deposits are characterized by the accumulation of sulphide minerals in three lithological forms analysed in this study i.e.: sandstone, shale and carbonates. In majority of the deposit these forms occur at the same time, but in different proportions. Metals in copper ores occur mainly in sulphide minerals. Basic copper minerals of Polish ores are copper sulphides such as: chalcocite $\left(\mathrm{Cu}_{2} \mathrm{~S}\right)$, bornite $\left(\mathrm{Cu}_{5} \mathrm{FeS}_{4}\right)$, chalcopyrite $\left(\mathrm{CuFeS}_{2}\right)$ and covelitte $(\mathrm{CuS})$. The main copper sulphide minerals are also carriers of accompanying elements such as: silver, lead, zinc, cobalt, nickel and gold. The average variance compositions of ore processed in the concentrators between 1985-1991 and 2009-2011 are presented in Table $1[13,9]$.

Table 1. KGHM S.A. deposit's changing of lithology structure

\begin{tabular}{|l|c|c|c|c|c|c|}
\hline \multirow{3}{*}{ Concentrator } & \multicolumn{2}{|c|}{ Sandstone } & \multicolumn{2}{c|}{ Shale } & \multicolumn{2}{c|}{ Carbonates } \\
\cline { 2 - 7 } & $1985-$ & $2009-$ & $1985-$ & $2009-$ & $1985-$ & $2009-$ \\
& 1991 & 2011 & 1991 & 2011 & 1991 & 2011 \\
\hline Lubin & $54.00 \%$ & $77.54 \%$ & $8.10 \%$ & $0.94 \%$ & $37.90 \%$ & $21.52 \%$ \\
\hline Polkowice & $9.90 \%$ & $22.67 \%$ & $5.90 \%$ & $5.28 \%$ & $84.20 \%$ & $72.05 \%$ \\
\hline Rudna & $43.30 \%$ & $54.11 \%$ & $5.50 \%$ & $11.56 \%$ & $51.20 \%$ & $34.33 \%$ \\
\hline
\end{tabular}

Sandstone ore has a light-grey colour it is fine grained, and compact. It contains mainly quartz, with small amounts of feldspars and other minerals. It is all bound together by a carbonate or clay binder. Metal bearing mineral particles are mostly no larger than $0.200\left[10^{-3} \mathrm{~m}\right]$, and in general, within a range of $0.050-0.200\left[10^{-}\right.$ $\left.{ }^{3} \mathrm{~m}\right]$. Carbonate ore occurs in the form of dolomites. Gangue minerals are mainly represented by dolomite, calcite, anhydrite and clay minerals. Metal bearing minerals mostly lay in a range of $0.030-0.200\left[10^{-3} \mathrm{~m}\right]$. Shale ore contains about $85 \%$ of clay minerals and carbonates, of which about $7 \%$ are organic matter with small amounts of quartz. Copper minerals are predominantly in the size range of $0.005-0.040\left[10^{-3} \mathrm{~m}\right][13,16]$.

It should be pointed out that, from an operational perspective, some of the copper bearing minerals have a grain size that is under the standardized limits i.e. it is difficult to float fine particles size range. Therefore, a change in the efficiency of fine particle flotation is one of the most important factors that can influence the possibility of increased $\mathrm{Cu}$ recovery. The lithological types of ore treated in KGHM S.A. concentrators have variable physicochemical properties, leading to the main reason for the implementation of the special conditions that are required for the grinding and flotation operations. 
The resources from Poland are some of the most complex in the world. These Polish copper deposits are rated among the most known difficult ones to process because of the following factors:

- the flotation times are relatively long due to the slow kinetics of sulphide mineral particles,

- three forms of lithology occur simultaneously, but in changing ratios, thereby creating a profound effect of the grinding and flotation conditions,

- a proper grinding process is mandatory for the fine and ultra-fine sulphide mineral particles,

- during the flotation process, high levels of impurities are recorded, such as organic carbon.

\section{MATERIALS AND METHODS}

The tests carried out in the KGHM S.A. concentrators showed that a majority (sometimes exceeding 60\%) of total metal loses came from the finest fraction of flotation of carbonates [13]. The grain size distribution of the minerals, and the associated gangue minerals, are the major factors that influence the concentration rates for the mineral and petrographic compositions of the ore that is processed in the Rudna concentrators.

Work presented in this paper has been carried out at Rudna Concentrator. Two sampling campaigns results are presented in this paper in the following chapters: 4.1 - which covers only results from the first sampling campaign focusing on impeller radial velocity influence

4.2 - which covers only results from the second sampling campaign focusing on both impeller radial velocity and air flow influence.

During the tests the impeller radial velocity in all rougher flotation machines was modified and the metallurgical output was measured. Samples were collected over a period of 6 days and each sample was sent for further metallurgical examination, including particle size and mineral liberation analyses. Six distinct cells collected 3 cascades as follow: I cascade -1 cell, II cascade -2 cells, III cascade -3 cells as contained by an investigating carbonates rougher flotation machine (IF-57). The identical impeller system parameters were supported by the actual flotation process in all flotation cells:

- diameter of the rotor $-940\left[10^{-3} \mathrm{~m}\right]$,

- radial velocity of the rotor $-2.0\left[\mathrm{~s}^{-1}\right]$,

- linear velocity of the rotor $-5.8\left[\mathrm{~s}^{-1} \mathrm{~m}\right]$.

The impeller radial velocity was changed using separate VFDs for all motors, as presented in Table 2. To better understand the influence of particle size on the 
flotation results only one parameter was tuned during this sampling campaign impeller radial velocity.

Table 2. Impellers radial velocity in each cascade established during sampling campaigns

\begin{tabular}{|c|c|c|c|c|c|c|c|c|c|}
\hline \multirow{2}{*}{$\begin{array}{l}\text { No. } \\
\text { cascade }\end{array}$} & \multicolumn{3}{|c|}{ Base case } & \multicolumn{3}{c|}{ Scenario I } & \multicolumn{3}{c|}{ Scenario II } \\
\cline { 2 - 10 } & RPM & $\mathrm{s}^{-1}$ & $\mathrm{~s}^{-1} \cdot \mathrm{m}$ & RPM & $\mathrm{s}^{-1}$ & $\mathrm{~s}^{-1} \cdot \mathrm{m}$ & RPM & $\mathrm{s}^{-1}$ & $\mathrm{~s}^{-1} \cdot \mathrm{m}$ \\
\hline I & 120 & 2.0 & 5.8 & 110 & 1.8 & 5.3 & 120 & 2.0 & 5.5 \\
\hline II & 120 & 2.0 & 5.8 & 120 & 2.0 & 5.8 & 110 & 1.8 & 5.3 \\
\hline III & 120 & 2.0 & 5.8 & 130 & 2.2 & 6.3 & 130 & 2.2 & 6.3 \\
\hline
\end{tabular}

This means that the collector and the frother furthered the volume, while the aeration of the pulp was created at a simultaneously constant amount during this flotation process. The flotation machine parameters were fixed at level maintain sufficient production performance and sustaining the same flotation conditions in all flotation cells bank [1].

During second sampling campaign not only the impeller radial velocity was analysed but also the influence of the air flow. Other parameters such as banks pulp levels were set at the same level, feed rate and collector dosage were also kept constant.

Test was run at the maximum, average and minimum values of the air flow and impeller radial velocity (Table 3).

Table 3. Tests conditions during second sampling campaign

\begin{tabular}{|c|c|c|c|c|c|c|c|c|c|c|}
\cline { 2 - 10 } \multicolumn{1}{c|}{} & \multicolumn{10}{c|}{} \\
\cline { 2 - 10 } & I & II & III & IV & V & VI & VII & VIII & IX & X \\
\hline Air flow $\left[\mathrm{m}^{3} / \mathrm{min}\right]$ & 6.0 & 8.0 & 6.0 & 6.0 & 5.0 & 5.0 & 6.0 & 8.0 & 6.0 & 8.0 \\
\hline $\begin{array}{c}\text { Impeller radial velocity } \\
{[\mathrm{RPM}]}\end{array}$ & 110 & 130 & 110 & 110 & 90 & 130 & 110 & 90 & 110 & 130 \\
\hline
\end{tabular}

During each sampling campaign the following samples were collected:

- flotation feed,

- concentrates from I, II and III cascades,

- ore sub-tailing sample from I cascade and II cascade,

- final tailings from III cascade.

The influence of the fine particles distribution on the flotation results was determined for the following received size fractions (above $0.315\left[10^{-3} \mathrm{~m}\right] ; 0.315-$ $0.2\left[10^{-3} \mathrm{~m}\right] ; 0.2-0.1\left[10^{-3} \mathrm{~m}\right] ; 0.1-0.075\left[10^{-3} \mathrm{~m}\right] ; 0.075-0.045\left[10^{-3} \mathrm{~m}\right]$; below 0.045 $\left.\left[10^{-3} \mathrm{~m}\right]\right)$. During each trial every copper grade as well as feed, concentrate and tailings densities were recorded. 


\section{RESULTS AND DISCUSSION}

\subsection{First sampling campaign - influence of impeller radial velocity}

During the sampling operations for five of the working milling segments, the overall average quantity of the grinding production line was sustained at levels of $820 \div 850\left[10^{3} \mathrm{~kg} / \mathrm{h}\right]$. Additionally, throughout of the entire test procedure feed density was established on the level of $1190 \div 1195\left[\mathrm{~m}^{-3} \cdot \mathrm{kg}\right]$.

For each campaign scenario, Fig. 1 shows the cumulated information of the particle size distribution curve for the feed that was directed to the carbonate rougher flotation.

\section{Feed Particile Size Distribution}

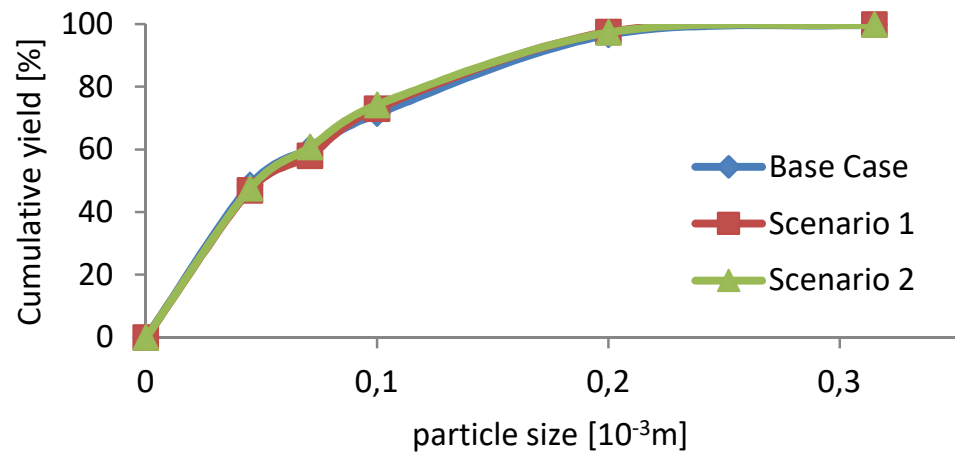

Fig. 1. Particle size distribution of the analysed feeds

Despite of slight particle size feed differences, processed during this sampling campaign still the influence of impeller velocity of the rougher performance can be observed as presented in Table 4.

Even though there are differences in the feeds that were processed during this sampling campaign, received results of concentration (as presented below) do show the influence of impeller velocity concerning the performance of the rougher operations.

Table 4. Copper ore processing results of variance between each scenario for impeller velocity

\begin{tabular}{|c|c|c|c|c|c|}
\hline \multirow{2}{*}{ Scenario } & \multicolumn{3}{|c|}{ Metal Content } & \multirow{2}{*}{$\begin{array}{c}\text { Concentration } \\
\text { Ratio }\end{array}$} & \multirow{2}{*}{$\begin{array}{c}\text { Recovery, } \\
\%\end{array}$} \\
\hline & Feed & Concentrate & Tailings & & \\
\hline \multicolumn{6}{|c|}{ Copper, $\%$} \\
\hline Base & 1.77 & 4.71 & 0.25 & 2.66 & 90.82 \\
\hline Scenario I & 1.70 & 4.82 & 0.21 & 2.83 & 91.78 \\
\hline Scenario II & 1.79 & 4.93 & 0.25 & 2.76 & 90.47 \\
\hline
\end{tabular}


With an average copper content of approx.1.77\% in the feed for the base case scenario, floated at 120 RPM for all cascades from the feed, $4.71 \%$ of the $\mathrm{Cu}$ concentrate grades were achieved at $90.82 \% \mathrm{Cu}$ recovery value. The highest copper content, of $6.01 \% \mathrm{Cu}$, was recorded for the concentrate from the first cascade. The second cascade showed a copper concentrate containing 3.89\% of $\mathrm{Cu}$. For the two first cascades, the amount of combined copper level recovery was recorded at $86.17 \%$. The third cascade had a concentrate grade that contained only $2.98 \%$ of copper, at the $\mathrm{Cu}$ recovery rate $4.65 \%$.

In the final tailings, the average copper concentration was $0.25 \% \mathrm{Cu}$. Based on received results following conclusions can be drawn:

- the quality of concentrate was established in the first two cascades,

- the final level of recovery was determined by the performance of third cascade.

\section{Cumulative recovery level in function of concentrate grade}

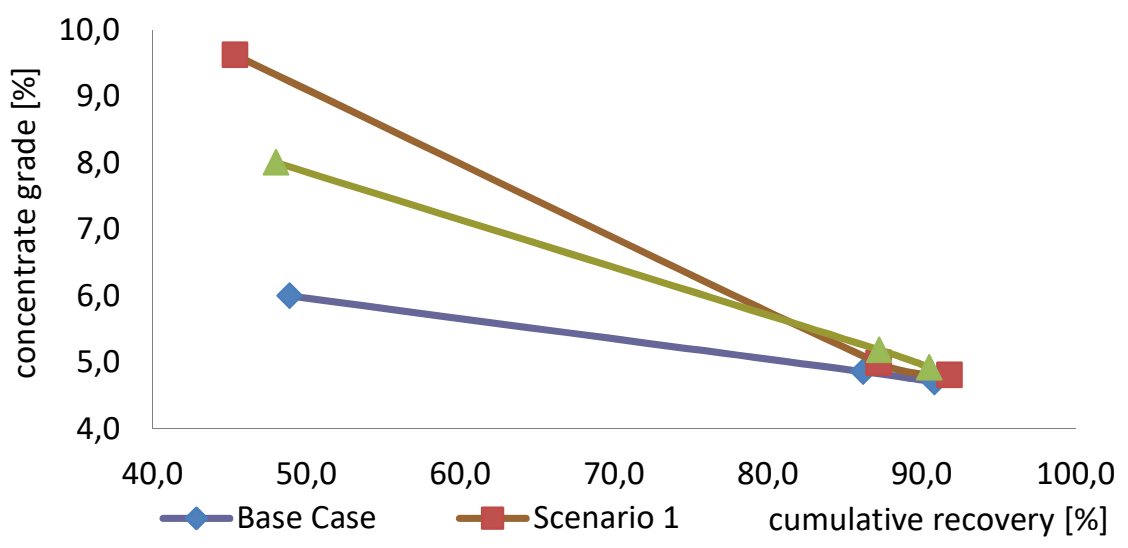

Fig. 2. Recovery level in the function of the concentrate grade

It was observed from the results of scenario 1 that the concentrate grade on the first cascade was $3.62 \%$. This is more than in the base case scenario grade value, however at the same time the recovery level of the first cascade shows a small negative impact. The increased impeller velocity in the third cascade during scenario 1 and scenario 2 test runs minimized the losses of copper in tailings. No significant influences were seen for the concentrate grades.

Size - by - size analysis for the concentrate were obtained for all cascades using the hypothetical feed, the results can be seen in the Table 5. The concentrate itself, and the size distribution analysis of the tailings have been calculated, as well as, the theoretical recoveries that were estimated for each size classes. A calculation was also conducted for the values of the copper content for all flotation products, 
as a weighted average for each particle size, including the copper content. The results for the simplified calculations described above are presented in Tables: 5, 6 and 7.

Table 5. Theoretical Particle Size Distribution of feeds, concentrates and tails -

Base Case

\begin{tabular}{|c|c|c|c|c|c|c|c|c|c|c|c|c|c|}
\hline \multirow{2}{*}{\begin{tabular}{|c|} 
Particle size \\
{$\left[10^{-3} \mathrm{~m}\right]$} \\
\end{tabular}} & \multicolumn{2}{|c|}{ Concentrate } & \multicolumn{2}{|c|}{$\gamma=38.34 \%$} & \multicolumn{2}{|l|}{ Tail } & \multicolumn{2}{|c|}{$=61.66 \%$} & \multicolumn{2}{|c|}{ Feed (calculated) } & \multicolumn{2}{|c|}{$\mathrm{Cu} \%=1.820$} & \multirow[b]{2}{*}{$\begin{array}{c}\text { Recovery } \\
{[\%]}\end{array}$} \\
\hline & $\gamma[\%]$ & $\Sigma \gamma[\%]$ & $\mathrm{Cu}[\%]$ & $\begin{array}{c}\text { Total } \\
\text { Recovery } \\
{[\%]}\end{array}$ & $\gamma[\%]$ & $\Sigma \gamma[\%]$ & $\mathrm{Cu}[\%]$ & $\begin{array}{c}\text { Total } \\
\text { Recovery } \\
{[\%]} \\
\end{array}$ & $\gamma[\%]$ & $\Sigma \gamma[\%]$ & $\mathrm{Cu}[\%]$ & \begin{tabular}{|c|} 
Total \\
Recovery \\
{$[\%]$} \\
\end{tabular} & \\
\hline+0.2 & 1.25 & 1.25 & 5.72 & 1.68 & 3.60 & 3.60 & 0.79 & 10.80 & 3.30 & 3.30 & 1.623 & 2.94 & 51.25 \\
\hline $0.2-0.1$ & 15.42 & 16.67 & 5.43 & 21.32 & 29.30 & 32.90 & 0.29 & 43.20 & 25.23 & 28.53 & 1.681 & 26.25 & 75 . \\
\hline $0.1-0.075$ & 14.60 & 31.27 & 4.41 & 36.41 & 10.93 & 43.83 & 0.27 & 54.28 & 11.00 & 39.53 & 2.305 & 40.18 & 97.32 \\
\hline $0.075-0.044$ & 16.51 & 47.78 & 3.91 & 51.53 & 9.83 & 53.66 & 0.26 & 64.12 & 11.67 & 51.20 & 2.240 & 54.54 & 94.61 \\
\hline-0.044 & 52.22 & 100.00 & 3.96 & 100.00 & 46.33 & 100.00 & 0.20 & 100.00 & 48.80 & 100.00 & 1.969 & 100.00 & 95.78 \\
\hline & 100.0 & & 4.27 & & 100.0 & & 0.26 & & 100.0 & & 1.820 & & 89.84 \\
\hline
\end{tabular}

Table 6. Theoretical Particle Size Distribution of feeds, concentrates and tails -

Scenario 1

\begin{tabular}{|c|c|c|c|c|c|c|c|c|c|c|c|c|c|}
\hline \multirow{2}{*}{\begin{tabular}{|c} 
Particle size \\
{$\left[10^{-3} \mathrm{~m}\right]$}
\end{tabular}} & \multicolumn{2}{|c|}{ Concentrate } & \multicolumn{2}{|c|}{$\gamma=30.40 \%$} & \multicolumn{2}{|l|}{ Tail } & \multicolumn{2}{|c|}{$=69.60 \%$} & \multicolumn{4}{|c|}{ Feed (calculated) $\quad \mathrm{Cu}^{2} \%=1.731$} & \multirow[b]{2}{*}{$\begin{array}{c}\text { Recovery } \\
{[\%]}\end{array}$} \\
\hline & $\gamma[\%]$ & $\Sigma \gamma[\%]$ & $\mathrm{Cu}[\%]$ & $\begin{array}{c}\text { Total } \\
\text { Recovery } \\
{[\%]}\end{array}$ & $\gamma[\%]$ & $\Sigma \gamma[\%]$ & $\mathrm{Cu}[\%]$ & $\begin{array}{c}\text { Total } \\
\text { Recovery } \\
{[\%]}\end{array}$ & $\gamma[\%]$ & $\Sigma \gamma[\%]$ & $\mathrm{Cu}[\%]$ & $\begin{array}{c}\text { Total } \\
\text { Recovery } \\
{[\%]} \\
\end{array}$ & \\
\hline 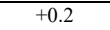 & 1.2 & 1.28 & 4.86 & 1.19 & 3.03 & $\overline{3.0}$ & 0.59 & 8.50 & 2.43 & 2.43 & 1.557 & 2.19 & 49.85 \\
\hline $0.2-0.1$ & 17.51 & 18.79 & 5.57 & 19.88 & 29.10 & 32.13 & 0.21 & 38.09 & 24.37 & 26.80 & 1.439 & 22.44 & 84.59 \\
\hline $0.1-0.075$ & 16.51 & 35.30 & 5.36 & 36.85 & 12.47 & 44.60 & 0.22 & 51.01 & 15.07 & 41.87 & 2.025 & 40.07 & 88.25 \\
\hline $0.075-0.044$ & 15.70 & 51.00 & 4.81 & 51.29 & 10.10 & 54.70 & 0.16 & 58.92 & 11.03 & 52.90 & 2.120 & 53.59 & 97.91 \\
\hline-0.044 & 49.01 & 100.00 & 5.19 & 100.00 & 45.30 & 100.00 & 0.19 & 100.00 & 47.10 & 100.00 & 1.706 & 100.00 & 96.20 \\
\hline & 100.0 & & 5.22 & & 100.0 & & 0.21 & & 100.0 & & 1.731 & & 91.66 \\
\hline
\end{tabular}

Table 7. Theoretical Particle Size Distribution of feeds, concentrates and tails -

Scenario 2

\begin{tabular}{|c|c|c|c|c|c|c|c|c|c|c|c|c|c|}
\hline \multirow{2}{*}{$\begin{array}{c}\text { Particle size } \\
{\left[10^{-3} \mathrm{~m}\right]}\end{array}$} & \multicolumn{2}{|c|}{ Concentrate } & \multicolumn{2}{|c|}{$\gamma=32.49 \%$} & \multicolumn{2}{|l|}{ Tail } & \multicolumn{2}{|c|}{$\gamma=67.51 \%$} & \multicolumn{4}{|c|}{ Feed (calculated) $\quad \mathrm{Cu} \%=1.873$} & \multirow[b]{2}{*}{$\begin{array}{c}\text { Recovery } \\
{[\%]}\end{array}$} \\
\hline & $\gamma[\%]$ & $\Sigma \gamma[\%]$ & $\mathrm{Cu}[\%]$ & $\begin{array}{c}\text { Total } \\
\text { Recovery } \\
{[\%]} \\
\end{array}$ & $\gamma[\%]$ & $\Sigma \gamma[\%]$ & $\mathrm{Cu}[\%]$ & $\begin{array}{c}\text { Total } \\
\text { Recovery } \\
{[\%]} \\
\end{array}$ & $\gamma[\%]$ & $\Sigma \gamma[\%]$ & $\mathrm{Cu}[\%]$ & $\begin{array}{c}\text { Total } \\
\text { Recovery } \\
{[\%]} \\
\end{array}$ & \\
\hline & & & & 0.94 & & & & 14.51 & 2.47 & 2.47 & 1.147 & 1.51 & 57.36 \\
\hline & & & & & & & & & & & & & \\
\hline $0.1-0.07$ & $1:$ & & & 34.46 & & 47. & & 49 . & & 39 & 2. & 37 & 95.55 \\
\hline $.0 / 3-6$ & 16 & & 5.02 & 50.1 & & & 0.28 & 58. & 13 & & 2.284 & & 89.88 \\
\hline-0.044 & 51.95 & 100.00 & & 100.00 & 43. & 100 & 0.25 & 100.00 & 47.70 & 100.00 & 1.838 & 100.00 & 97.87 \\
\hline & 100.0 & & 5.30 & & 100.0 & & 0.26 & & 100.0 & & 1.873 & & 91.93 \\
\hline
\end{tabular}

As a consequence of the changing impeller radial velocity, the variability of concentrate product particle size distribution was observed. In scenario 1 , the particle size distribution analyses of tailing products showed the lowest total copper losses $(\mathrm{Cu}$ grade $0.21 \%)$, due to minimized $\mathrm{Cu}$ loses achieved in the coarsest size fractions $+0.1\left[10^{-3} \mathrm{~m}\right](38.09 \% \mathrm{Cu})$.

\subsubsection{Mineralogy analysis of $\mathrm{Cu}$ concentrates}

Mineralogical survey for all scenarios were performed on the scavenger flotation concentrates to find out what adjustments need to be done to improve flotation performance. 


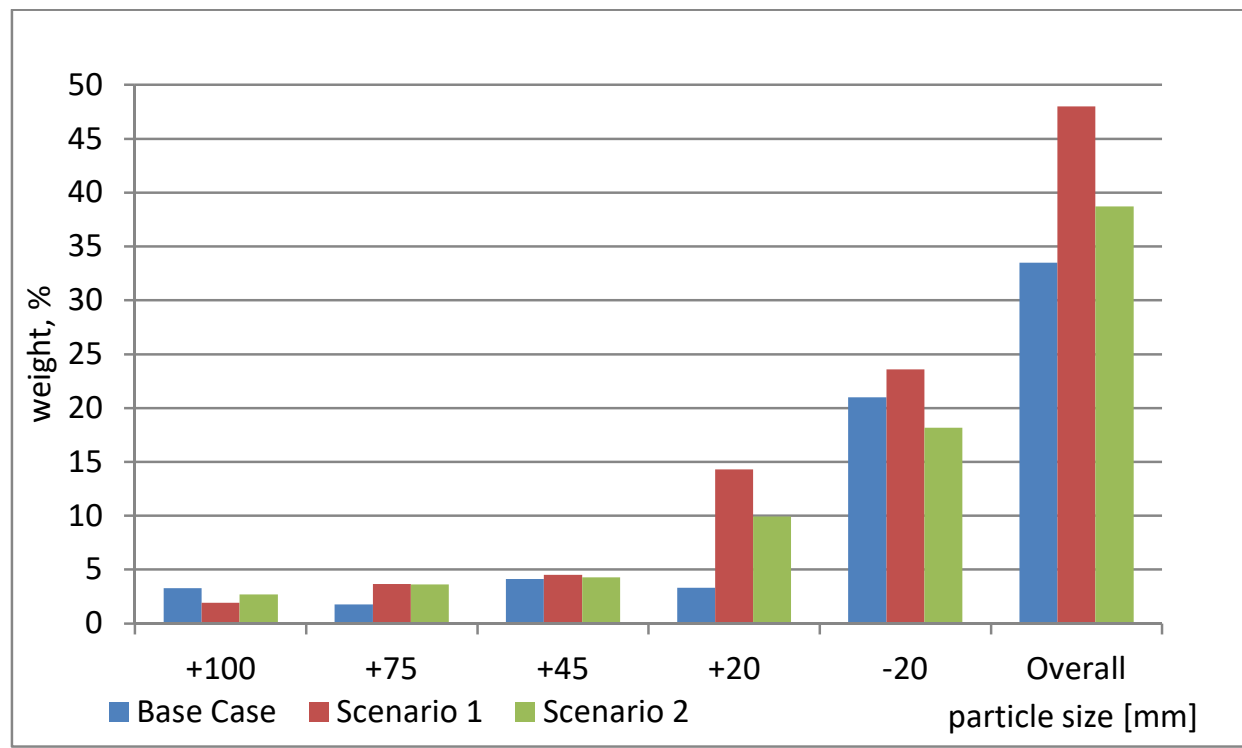

Fig. 3. Size by size liberation analysis of copper liberated sulphide minerals for the first cascade rougher concentrates

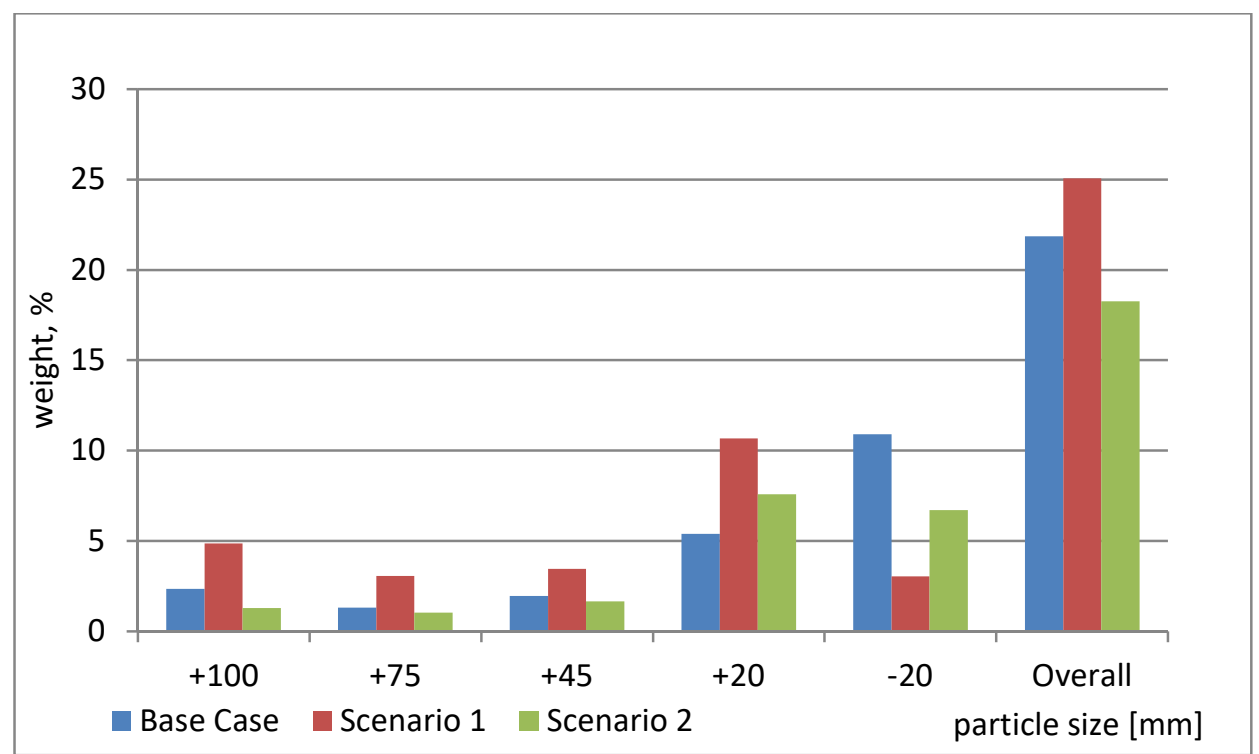

Fig. 4 Size by size liberation analysis of copper middling sulphide minerals for the third cascade rougher concentrates

In the example of the presented flotation details about the mineralogical survey, it can be noticed in Fig. 3, 4 and 5 that the recovery of the liberated copper sulphide minerals in the concentrates from the first cascade is the highest in 
scenario 1 . This can also be correlated with the results that were previously presented in this paper for the concentrate grades assays. In the third cascade, it is shown that the increases in the impeller radial velocity had the most positive influence on the recovery of middling and locked copper sulphide minerals in scenario 1; as majority of those particles (middling and locked) has the larger particle size than liberated ones.

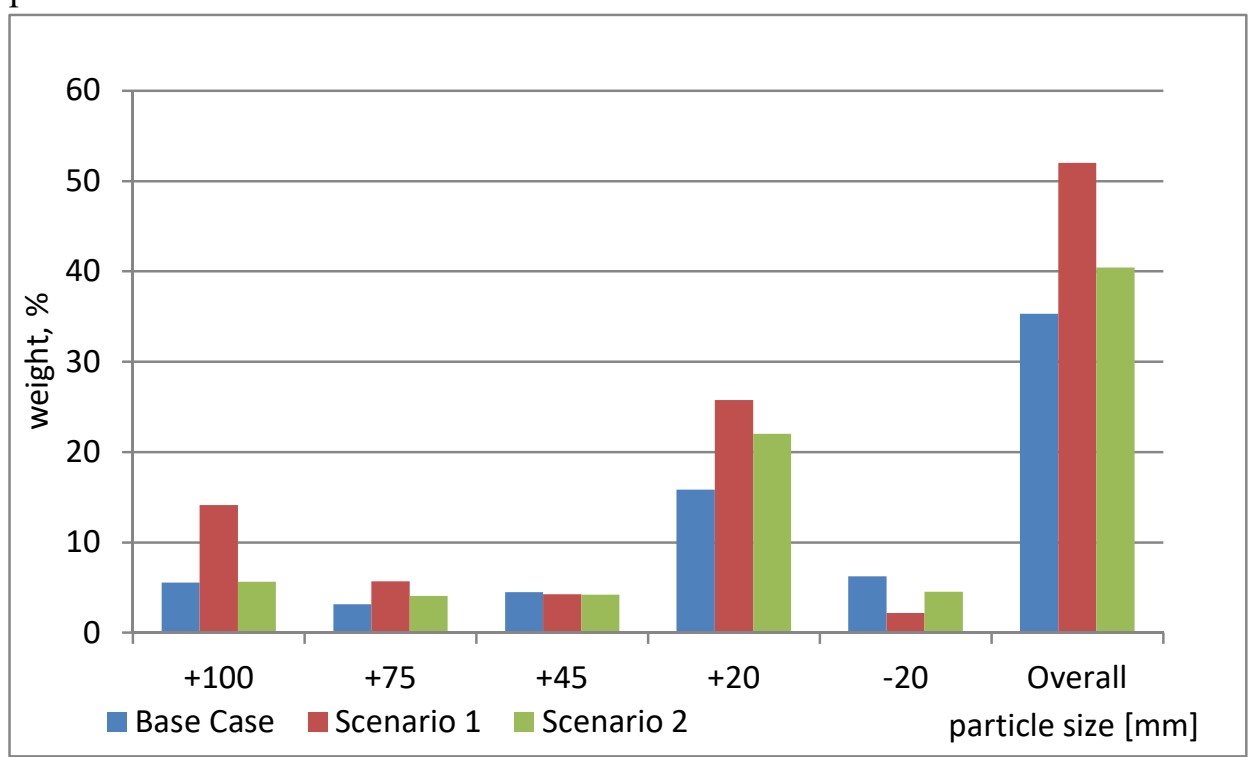

Fig.5 Size by size liberation analysis of copper locked sulphide minerals for the third cascade rougher concentrates

\subsection{Second sampling campaign - influence of air flow and impeller radial velocity on flotation}

Results of the previous sampling campaign have proved that impeller radial velocity influenced the flotation performance. According to this, authors decided to preform additional sampling campaign which results would bring the final conclusions. In this campaign the two different mechanical parameters of the process were adjusted (air flow and impeller radial velocity). Chemical assays of this campaign can be seen in Table 8 .

The highest recoveries were obtained in tests II (94.86\%) and X $(91.73 \%)$ with the $\mathrm{Cu}$ grade of $6.07 \%$ and $7.37 \%$ respectively. For both tests impeller speed and air flow rate were set at the highest analyzed levels. Concentration ratio of this process was on the lowest level of 2.51 and 3.26 which is one of the main objective in this stage of flotation process (rougher stage). 
The highest concentrate grade with the highest concentration ratio (6.63) was produced in the conditions of $\mathrm{V}$ test at the lowest for both air flow rate and impeller radial velocity. In this test $\mathrm{Cu}$ grade was $11.48 \%$, but the recovery decreased to $70.56 \%$. The other low recovery value $78.95 \%$ has been recorded in test VIII at $\mathrm{Cu}$ grade of $7.77 \%$, and concentration level of 4.27 .

Test I, III, IV, VII and IX were run in the same conditions. Results from tests III and IV are comparable with recoveries of $86.16 \%$ and $85.34 \%$ and $\mathrm{Cu}$ grades of $7.68 \%$ and $7.37 \%$ respectively. The concentration ratio for those tests was approximately the same (3.90 and 3.94). Also in the case of test VII and IX recoveries were at the same range of $84.35 \%$ and $86.71 \%$, but $\mathrm{Cu}$ grade were lower $6.29 \%$ and $6.81 \%$ which follows the difference of copper content in the feed $1.72 \%$ and $1.93 \%$ respectively. Test I has the highest recovery of $89.50 \%$ but still low $\mathrm{Cu}$ grade of $6.30 \%$ which also is consequence the highest copper content in the feed $(2.08 \%)$. The test I can be regarded as calibration test and it's results should not be taken into account.

Table 8. $\mathrm{Cu}$ grades of different products (where: F-Feed; C-Concentrate; T-Tailings)

\begin{tabular}{|c|c|c|c|c|c|c|c|c|c|c|c|c|}
\hline \multirow{3}{*}{$\begin{array}{l}\text { TEST } \\
\text { RUN }\end{array}$} & \multicolumn{3}{|c|}{ I Cascade } & \multicolumn{3}{|c|}{ II Cascade } & \multicolumn{3}{|c|}{ III Cascade } & \multirow{2}{*}{\multicolumn{3}{|c|}{ Final concentrate }} \\
\hline & $\mathrm{F}$ & $\mathrm{C}$ & $\mathrm{T}$ & $\mathrm{F}$ & $\mathrm{C}$ & $\mathrm{T}$ & $\mathrm{F}$ & $\mathrm{C}$ & $\mathrm{T}$ & & & \\
\hline & \multicolumn{9}{|c|}{$\mathrm{Cu}$ grades $[\%]$} & $\begin{array}{c}\mathrm{Cu} \\
\text { grade } \\
{[\%]}\end{array}$ & $\begin{array}{c}\text { Recovery } \\
{[\%]}\end{array}$ & $\begin{array}{l}\text { Concentration } \\
\text { ratio }\end{array}$ \\
\hline I & 2.08 & 9.43 & 1.27 & 1.27 & 5.08 & 0.49 & 0.49 & 3.42 & 0.31 & 6.30 & 89.50 & 3.03 \\
\hline II & 2.42 & 7.71 & 1.22 & 1.22 & 4.59 & 0.37 & 0.37 & 4.02 & 0.20 & 6.07 & 94.86 & 2.51 \\
\hline III & 1.97 & 10.43 & 0.99 & 0.99 & 5.65 & 0.44 & 0.44 & 3.53 & 0.35 & 7.68 & 86.16 & 3.90 \\
\hline IV & 1.87 & 10.52 & 1.12 & 1.12 & 6.12 & 0.50 & 0.50 & 3.84 & 0.35 & 7.37 & 85.34 & 3.94 \\
\hline $\mathrm{V}$ & 1.73 & 21.04 & 1.14 & 1.14 & 8.84 & 0.67 & 0.67 & 4.95 & 0.57 & 11.48 & 70.56 & 6.63 \\
\hline VI & 1.63 & 12.80 & 0.82 & 0.82 & 5.12 & 0.34 & 0.34 & 3.44 & 0.26 & 7.77 & 86.96 & 4.77 \\
\hline VII & 1.72 & 10.67 & 1.13 & 1.13 & 5.19 & 0.55 & 0.55 & 3.53 & 0.35 & 6.29 & 84.35 & 3.66 \\
\hline VIII & 1.82 & 12.85 & 1.31 & 1.31 & 7.13 & 0.66 & 0.66 & 4.12 & 0.47 & 7.77 & 78.95 & 4.27 \\
\hline IX & 1.93 & 9.52 & 1.13 & 1.13 & 5.42 & 0.45 & 0.43 & 3.56 & 0.34 & 6.81 & 86.71 & 3.53 \\
\hline $\mathrm{X}$ & 2.26 & 9.47 & 1.15 & 1.15 & 5.73 & 0.32 & 0.32 & 3.22 & 0.26 & 7.37 & 91.73 & 3.26 \\
\hline
\end{tabular}

A selectivity of the process is presented in Table 9. The highest selectivity of the process at 0.97 range was achieved in the test II and IX, also test X were close to this range (0.967). It is caused by higher air flow and impeller radial velocity during flotation process [4].

The lowest selectivity of the process $(0.943)$ was obtained for the test $\mathrm{V}$, where process parameters were set at the lowest measurable range (Tab. 9). 
IMPELLER RADIAL VELOCITY AND AIR FLOW RATE INFLUENCE ON COPPER $\quad 51$ ROUGHER FLOTATION RECOVERY

Table 9. Selectivity of process for different tests in the second sampling campaign

\begin{tabular}{|c|c|c|c|c|c|c|c|c|c|c|}
\cline { 2 - 10 } \multicolumn{1}{c|}{} & \multicolumn{10}{c|}{ TEST RUN } \\
\cline { 2 - 11 } \multicolumn{1}{c|}{} & I & II & III & IV & V & VI & VII & VIII & IX & X \\
\hline Selectivity & 0.954 & 0.968 & 0.968 & 0.947 & 0.943 & 0.954 & 0.956 & 0.955 & 0.968 & 0.967 \\
\hline
\end{tabular}

\section{CONCLUSIONS}

The following conclusions can be drawn the received results analysing the impeller velocity and air flow influence on the flotation:

- based on the first sampling campaign, the best results in the rougher flotation process were achieved for the gradually increased impeller velocity from the first to the last cascade i.e. from $1.8\left[\mathrm{~s}^{-1}\right]$, via $2.0\left[\mathrm{~s}^{-1}\right]$ up to $2.2\left[\mathrm{~s}^{-1}\right]$; which indicated requirements for more precise range of impeller velocity for second, more detailed test work,

- based on the mineralogical analysis results from the first sampling campaign a positive impact of increased impeller velocity on the recovery of rougher flotation can be seen. Higher impeller velocity enhances floatability of middling and locked particles from mid and coarser size fractions,

- received results from second sampling campaign test $\mathrm{V}$ confirmed positive impact of the elevated impeller radial velocity on the total recovery of rougher flotation however, the best results measured by the higher recoveries were achieved when both impeller velocity and air flow rates were at the highest investigated levels (test II and X).

\section{ACKNOWLEDGEMENTS}

The authors would like to acknowledge the management of the KGHM S.A. Division of Concentrators in the development of this work and paper, CBJ sp. z o.o. Environmental and industrial studies, KGHM CUPRUM sp. z o.o. Research and Development Center. Special thanks are extended to Andrzej Konieczny for initiating the MLA Survey at KGHM Division of Concentrators, directing the metallurgical efforts for optimizing the copper recovery.

\section{REFERENCES}

1. Bazan B., Kasinska-Pilut E., Garbacki M., Bazan-Krzywoszanksa A.: The influence of copper mineralogy and impeller speed on the $\mathrm{Cu}$ recovery of scavengers in KGHM Polska Miedz S.A., International Mineral Engineering Congress 2014 IMEC, Mexico, San Luis Potosi. 
2. Bortel R.: Wpływ minerałów ilastych na flotowalność siarczków metali nieżelaznych, Gliwice, Politechnika Śląska 1967.

3. Deglon D. A.: A hydrodynamic investigation of fine particle flotation in a batch flotation cell, University of Cape Town, South Africa 1998.

4. Doyle F. M., Kelsall G. H., Woods R.: Electrochemistry in Mineral and Metal Processing, VI: Proceedings of the International Symposium, The Electrochemical Society, USA 2003.

5. Greame J., Jameson G.: The effect of surface liberation and particle size on flotation rate constants, Minerals Engineering, Vol 36-38, 10 (2012) 132137

6. Grano S.: Effect of impeller rotational speed on the size dependent flotation rate of galena infull scale plant cells, Minerals Engineering 19 (2006) 1307 1318.

7. Grotowski A., Mizera A., Grotowska M.: Możliwości i warunki zagospodarowania odpadów powstających przy eksploatacji i przeróbce rud miedzi, Problemy zagospodarowania odpadów mineralnych, Sekcja Wykorzystania Surowcow Mineralnych Komitetu Górnictwa Polskiej Akademi Nauk, Agencja Gospodarki Odpadami „AGOS” S.A. w Katowicach, (1995) 53-67.

8. Kendrick M., Baum W., Thompson P., Wilkie G., Gottlieb P.: The use of the QemSCAN automated mineral analyzer at the Candelaria concentrator In C.O. Gomez \& C.A. Barahona (Eds.), Copper-Cobre 2003, Vol. III: Mineral Processing 2003,415-430.

9. Konieczny A., Bazan B.: Challenges and difficulties of comminution processes in KGHM S.A. Division of Concentrators, MEI Conference Comminution'12, Cape Town, South Africa, April 2012.

10. Lelinski D., Govender D., Dobrowski B., Traczyk F.: Executive use of energy in the flotation process, The Southern African Institute of Mining and Metallurgy, 6th Southern African Base Metals Conference 2011, pp. (2011) 137-148.

11. Luszczkiewicz A., Wieniewski A.: Kierunki rozwoju technologii wzbogacania rud w krajowym przemyśle miedziowym, Górnictwo I Geoinzynieria, Rok 30, Zeszyt 3/1, AGH Uczelniane Wydawnictwa Naukowo - Dydatktyczne, ISSN: 1732-6702 (2006) 181-196.

12. Massey W.T., Harris M., Deglon D.A.: Investigating the effect of energy input on flotation kinetics in an oscillating grid flotation cell, Minerals Engineering, Vol. 36-38, 10, (2012) 145-151

13. Potulska A.: Analysis of Fine Particles Behaviour in Flotation of Polish Copper Ores, Copper 2010 GDMB Conference, Hamburg, Germany, vol.7, ISBN 978-3-940276-31-5, (2010) 2859-2872. 
14. Puget F. P., Melo M. V., Massarani G.: Modelling of the dispersed air flotation process applied to dairy wastewater treatment, Braz. J. Chem. Eng, vol.21 no.2, São Paulo 2004

15. Schubert H.: On the optimization of hydrodynamics in fine particle flotation, Minerals Engineering 21, (2008) 930-936.

16. Spalińska B, Stec R., Sztaba K.: Miejsce I rola przeróbki rudy w kompleksie technologicznym KGHM Polska Miedz S.A., In: Monografia KGHM Polska Miedz S.A., Część II, Praca zbiorowa pod redakcja Piestrzynski A., Wyd. KGHM Cuprum CBR, Spolka z o.o., Wroclaw, Lubin, pp. 463-472, 2007.

\section{WPŁYW PRĘDKOŚCI OBROTOWEJ WIRNIKÓW I STOPNIA NAPOWIETRZENIA ZAWIESINY FLOTATYCJNEJ NA PRZEBIEG OPERACJI FLOTACJI GŁÓWNEJ MIEDZI}

\section{Streszczenie}

W pracy przeprowadzono analizę wpływu składu mineralogicznego nadawy kierowanej do procesu flotacji głównej, wielkości przepływu dozowanego powietrza i prędkości obrotowej wirników na wyniki flotacji miedzi. Produkty procesu zostały poddane analizom chemicznym oraz mineralogicznym $\mathrm{z}$ wykorzystaniem systemu MLA. Przeprowadzone analizy wykazały, ze optymalizacja uzysku miedzi flotacji głównej $\mathrm{w}$ warunkach przemysłowych, limitowana jest obecnością w nadawie uwolnionych minerałów miedzi w skrajnych klasach ziarnowych. W artykule przedstawiono wyniki eksperymentów realizowanych $\mathrm{w}$ warunkach przemysłowych i pozytywny wpływ modyfikacji prędkości obrotowej wirników oraz stopnia napowietrzenia zawiesiny flotacyjnej na uzysk miedzi.

Słowa kluczowe: flotacja, rudy miedzi, stopień uwolnienia

Editor received the manuscript: 3.01 .2018 